\title{
A new species of Eupithecia Curtis (Lepidoptera, Geometridae) from the Azapa Valley, northern Chile
}

\author{
Héctor A. Vargas ${ }^{1}$
}

'Departamento de Recursos Ambientales, Facultad de Ciencias Agronómicas, Universidad de Tarapacá, Casilla 6-D, Arica, Chile. havargas@uta.cl

\begin{abstract}
A new species of Eupithecia Curtis (Lepidoptera, Geometridae) from the Azapa Valley, northern Chile. Male and female adults of a new species of Eupithecia Curtis from the Arica Province, Chile are described and illustrated. The species is compared with E. yubitzae Vargas \& Parra, 2004, from the same locality, and E. galapagosata Landry \& Rindge 1995, from the Galapagos Islands, Ecuador.
\end{abstract}

KEYWORDS. Eupithecia galapagosata; Eupithecia yubitzae; Neotropical; taxonomy.

RESUMO. Uma nova espécie de Eupithecia Curtis (Lepidoptera, Geometridae) do Vale de Azapa, norte do Chile. Macho e fêmea de uma nova espécie de Eupithecia Curtis da Província de Arica, Chile são descritos e ilustrados. A espécie é comparada com $E$. yubitzae Vargas \& Parra, 2004, da mesma localidade, e E. galapagosata Landry \& Rindge 1995, das Ilhas Galápagos, Equador.

PALAVRAS-CHAVE. Eupithecia galapagosata; Eupithecia yubitzae; Neotropical; taxonomia.

Eupithecia Curtis, 1825 is a diverse and widespread genus of Geometridae with more than 1300 described species (Scoble 1999; Herbulot 2001). More than 60 species have been reported for the Chilean fauna (Herbulot 2001), but only four occur in the northernmost desert (Rindge 1987, 1991; Vargas \& Parra 2004, 2005). Vojnits (1985) proposed three Chilean genera, which were subsequently synonymised with Eupithecia by Rindge (1987). Rindge (1987, 1991) divided the Chilean species into two sections mostly based on the morphology of the sclerites of the male eighth segment. However, additional efforts are required to obtain a better understanding of the phylogenetic relationships of Eupithecia.

Larvae of Eupithecia are generally phytophagous. However, many endemic species may be ambush predators in the Hawaiian Islands (Montgomery 1982). Host plants have been mentioned for only six Chilean Eupithecia, including the families Chenopodiaceae, Fabaceae and Gunneraceae (IbarraVidal \& Parra 1993; Parra \& Ibarra-Vidal 2002; Vargas \& Parra 2002, 2004, 2005; Vargas et al. 2002).

Eupithecia yubitzae Vargas \& Parra, 2004 was until recently the only species of this genus known for the coastal valleys of the Arica Province, northern Chile. In March 2009, male and female of an undescribed species of Eupithecia were collected at light. Thus, the purpose of this work is to present a description of the adults of this new species.

Type material will be deposited in the Museo Nacional de Historia Natural de Santiago (MNNC), Santiago, Chile.

\section{Eupithecia landryi Vargas sp. nov.}

(Figs. 1-6)

Type material. Holotype male. CHILE, Arica: Azapa, Arica, Chile; March 2009; H.A. Vargas coll. (MNNC). Paratype: one female, same data as holotype (MNNC).
Diagnosis. Small geometrid moth $(5.9 \mathrm{~mm}$ forewing length in the holotype) with filiform antennae, male with a tuft of elongated, white scales on the ventral surface of the forewing arising near the wing base, among the discal cell and anal veins; sternite VIII composed by two longitudinal sclerotized stripes, each stripe with lateral and median margins broadly concave, anterior and posterior margins round; male genitalia with vesica bearing two cornuti, the largest cornutus elongated, slightly curved, with a short distal projection; female genitalia characterized by the presence of two groups of the spine-like signa: one proximal with bigger spine-like signa and another distal with shorter signa.

Male (Fig. 1). Head. Front, vertex and occiput light reddish brown; labial palpi pale brown with scattered dark brown scales, long around 1.5 times eye diameter; antennae filiform, dorsal surface with transversal stripes of scales pale brown and dark brown alternate, ventral surface ciliate; chaetosema a narrow transverse stripe between vertex and occiput. Thorax light reddish brown dorsally with dark brown scales scattered, pale brown laterally. Legs yellowish brown with dark brown scales mostly concentrated on the tibia and tarsus, tibiae of middle and hindlegs with one and two pairs of yellowish brown spines, respectively. Forewing $(5.9 \mathrm{~mm}$ length in the holotype): dorsal surface reddish brown with dark brown scales scattered; ventral surface pale brown with dark brown and light reddish brown scales, a tuft of elongated, white scales arising near the wing base, among the discal cell and the anal veins. Hindwing: dorsal color pattern similar to forewing, with a marked basal depression near costal margin for receiving the tuft of the forewing; ventral color pattern as that of the forewing. Abdomen mostly light reddish brown with pale brown and dark brown scales scattered; tergite VIII (Fig. 4) with lateral margins broadly concave, posterior margin round; sternite VIII (Fig. 5) composed 
of two longitudinal sclerotized stripes, each stripe with lateral and median margins broadly concave, anterior and posterior margins round.

Male genitalia (Figs. 3, 4). Uncus short, pointed apex; tegumen and saccus straight; juxta ellipsoid basally, with striking lateral constrictions, distal margin broadly concave; transtilla well developed; papillae digitiform, elongated, with small setae distally; valva broad basally, straight toward the apex; costa not reaching the distal end of the valva, saccular area with a fold at base. Aedeagus cylindrical, about $2 / 3$ the length
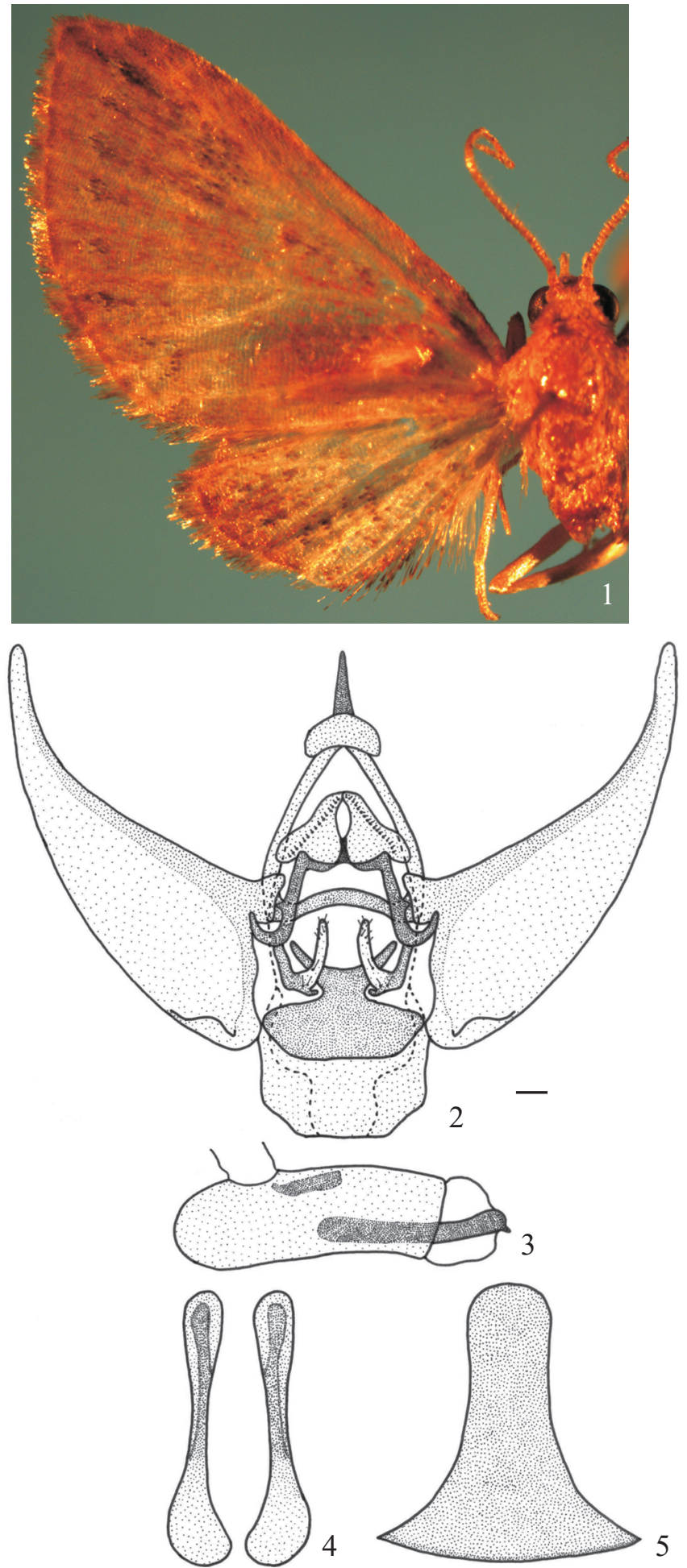

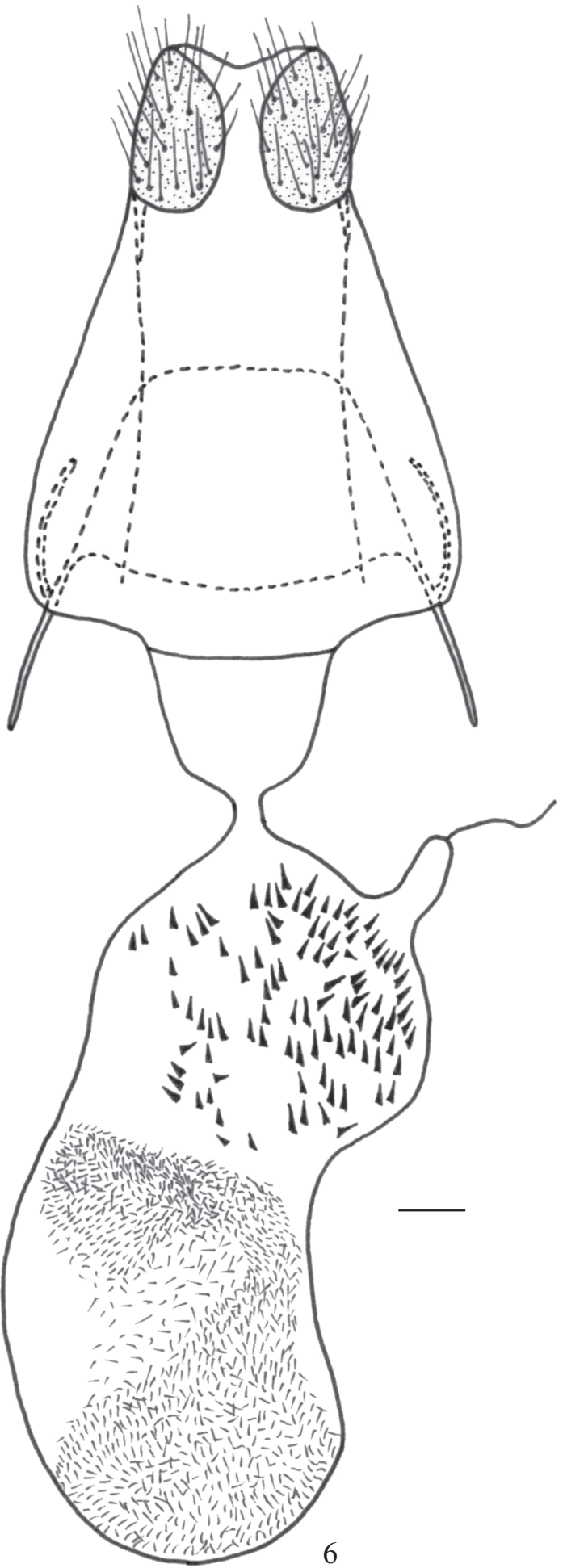

Figs. 1-6. Eupithecia landryi: 1, male holotype, dorsal view; 2, male genitalia, ventral view (aedeagus removed); 3, aedeagus, lateral view; 4, sternite VIII, ventral view; 5 , tergite VIII, dorsal view; 6 , female genitalia, ventral view. Scale: $0.1 \mathrm{~mm}$. 
of the valva; vesica with two cornuti, one of them with approximately $3 / 4$ the length of the aedeagus, elongated, slightly curved, with a short distal projection; the other cornutus with approximately $1 / 4$ the length of the aedeagus, cylindrical and straight.

Female. Similar to male. Forewing without tuft of scales on the ventral surface. Hindwing without a marked basal depression near costal margin on the dorsal surface.

Female genitalia (Fig. 6). Antrum broad, membranous; ductus bursae straight, membranous, about $1 / 3$ the length of the antrum; corpus bursae elongated, membranous, with two groups of spine-like signa, one proximal with large signa, and the other distal with smaller signa; appendix bursae membranous, cylindrical, twice the length of the ductus bursae, arising from the right lateroposterior area; ductus seminalis arising at apex of the appendix bursae; sterigma not differentiated; anterior apophyses straight and long, with a posterior projection at base; posterior apophyses straight and elongated, reaching the anterior margin of tergite VIII.

Etymology. Eupithecia landryi is named in honor of Dr. Bernard Landry by his outstanding contributions on Lepidoptera of the Galapagos Islands, Ecuador.

Hostplant. Unknown.

Remarks. Eupithecia landryi is the second species of Eupithecia described from the coastal valleys of the northern desert of Chile. Morphology of the male genitalia of $E$. landryi is strikingly similar to that of E. yubitzae, the other species of the genus recorded in the area, and E. galapagosata Landry \& Rindge, 1995, from the Galapagos Islands, Ecuador (Landry \& Rindge 1995). This morphological pattern, characterized by a short and pointed uncus, valvae narrowing distally, long and digitiform papillae, and vesica with at least one cornutus longer than the half of the aedeagus, may indicate a possible phylogenetic relationship among these species. However, some morphological features of the male genitalia allow to separate E landryi from E. galapagosata and E. yubitzae: a reduced number of cornuti, and the shape of the larger cornutus. On the other hand, morphology of the female genitalia of E. landryi is also similar to that of E. yubitzae and E. galapagosata. However, in E. landryi the corpus bursae and the appendix bursae are membranous, and the appendix bursae arises from the lateroposterior area of the corpus bursae, while in E. yubitzae and E. galapagosata the corpus bursae is sclerotized basally, and the appendix bursae, which is sclerotized, arises distally in the corpus bursae.

The Eupithecia species of the coastal desert of southern Peru and northern Chile are still poorly known and it is possible that other undescribed species may occur in this area. Eupithecia landryi is known only from the type locality, the Azapa Valley. Additional fieldwork along the coastal desert of southern Peru and northern Chile is necessary for a better knowledge of the geographic distribution of the geometrid moths of this very interesting ecosystem.

\section{ACKNOWLEDGEMENT}

This study was supported by project Diexa-Uta 9710-10.

\section{REFERENCES}

Herbulot, C. 2001. On Neotropical Eupithecia. Spixiana 24: 196.

Ibarra-Vidal, H. \& L. E. Parra. 1993. Descripción de los estados preimaginales y aspectos de la historia natural de Eupithecia horismoides Rindge 1987 (Lepidoptera: Geometridae), perforados del pecíolo del pangue (Gunnera tinctoria). Revista Chilena de Entomología 20: 35-41.

Landry, B. \& F. H. Rindge. 1995. Additions to the Geometridae (Lepidoptera) of the Galapagos Islands, Ecuador, including a new species of Eupithecia. American Museum Novitates 3118: 1-10.

Montgomery, S. L. 1982. Biogeography of the moth genus Eupithecia in Oceania and the evolution of the ambush predation in Hawaiian caterpillars (Lepidoptera: Geometridae). Entomologia Generalis 8: 27-34.

Parra, L. E. \& H. Ibarra-Vidal. 2002. A new species of Eupithecia (Lepidoptera: Geometridae) of Juan Fernández Islands. Annals of the Entomological Society of America 95: 9-15.

Rindge, F. H. 1987. The Eupithecia of Chile (Lepidoptera, Geometridae). Bulletin of the American Museum of Natural History 186: 269-363.

Rindge, F. H. 1991. The Eupithecia of Chile (Lepidoptera, Geometridae) II. American Museum Novitates 3020: 1-14.

Scoble, M. J. 1999. Geometrid moths of the world: a catalogue (Lepidoptera, Geometridae). Victoria, CSIRO Publishing, xxv+1016 p.

Vargas, H. A. \& L. E. Parra. 2002. Notas sobre Eupithecia atacama (Vojnits) (Lepidoptera: Geometridae). Idesia 20: 27-33.

Vargas, H. A. \& L. E. Parra. 2004. Una nueva especie de Eupithecia Curtis (Lepidoptera: Geometridae) del extremo norte de Chile. Revista Chilena de Historia Natural 77: 485-490.

Vargas, H. A. \& L. E. Parra. 2005. Descripción de una nueva especie de Eupithecia Curtis (Lepidoptera: Geometridae) de la Pampa del Tamarugal, Chile. Neotropical Entomology 34: 215-219.

Vargas, H. A.; L. E. Parra; H. E. Vargas \& D. E. Bobadilla. 2002. Aspectos biológicos de Eupithecia sibylla Buttler 1882 (Lepidoptera: Geometridae). Gayana 66: 103-106. 